\title{
KUALITAS ORGANOLEPTIK DAN NILAI pH KULIT KOPI YANG DIFERMENTASI DENGAN PENAMBAHAN LEVEL Trichoderma sp. YANG BERBEDA
}

\section{The Organoleptic Quality and pH Value of Fermented Coffee Peel with the Addition of Different Level of Trichoderma sp.}

\author{
Hasan Basri ${ }^{1}$, Ach. Syamsuddin', dan Dewi Ratih Ayu Daning1 \\ 1 Jurusan Penyuluhan Peternakan dan Kesejahteraan Hewan, \\ Politeknik Pembangunan Pertanian Malang \\ Email: basrihsn31@gmail.com
}

\begin{abstract}
INTISARI
Penelitian ini bertujuan untuk mengetahui kualitas organoleptik dan nilai pH kulit kopi yag difermentasi Trichoderma sp. pada level yang berbeda. Perlakuan kulit kopi yang difermentasi Trichoderma sp. dalam penelitian ini, yaitu: P0 (tanpa Trichoderma sp.), P1 (7,5 g), P2 (15,0 g), dan P3 (22,5 g). Setiap perlakuan terdiri dari 4 ulangan. Parameter yang diamati meliputi: kualitas organoleptik (warna, aroma, dan tekstur), dan nilai pH. Uji organoleptik dilakukan dengan penilaian menggunakan metode skoring oleh 12 panelis. Data hasil uji dianalisis dengan analisis variansi (ANOVA), jika terdapat pengaruh terhadap peubah yang berbeda maka dilanjutkan dengan uji lanjut Duncan Multiple Range Test (DMRT). Fermentasi limbah kulit kopi dengan Trichoderma sp. menghasilkan kualitas dengan warna rata-rata coklat terang, aroma asam, dan tekstur yang semakin lembek dengan peningkatan persentase pemberian Trichoderma sp. Nilai pH fermentasi kulit kopi dengan Trichoderma sp. yaitu sekitar 6 .
\end{abstract}

Kata kunci: Fermentasi, Kulit Kopi, Kualitas Organoleptik, Trichoderma sp.

\section{ABSTARCT}

This study aimed to determine the quality of organoleptic and $\mathrm{pH}$ value of fermented coffee peel using Trichoderma sp. at different levels. The treatment of coffee peel fermented using Trichoderma sp. consisted of P0 (without Trichoderma sp.), P1 (7.5 g), P2 (15.0 g), and P3 (22.5 g). Each treatment consisted of 4 replications. The parameters observed included: organoleptic quality (color, aroma, and texture) and $\mathrm{pH}$ value. The organoleptic test using the scoring method by 12 panelists. The result was analyzed by analysis of variance (ANOVA). A comparison among different treatments was performed by Duncan Multiple Range Test (DMRT). Fermentation of coffee peel waste with Trichoderma sp. produces average light brown color, sour aroma, and softer texture with an increasing percentage of Trichoderma sp. The $\mathrm{pH}$ value of coffee peel fermentation with Trichoderma sp. ranged around 6.

Keywords: Fermentation, Coffee Peel, Quality of Organoleptic. Trichoderma sp.

\section{PENDAHULUAN}

Kecamatan Pakem merupakan salah satu wilayah penghasil kopi yang cukup besar kedua di Kabupaten Bondowoso setelah Kecamatan Ijen. Luas tanaman kopi Robusta di kawasan hutan mencapai 4,75 Ha dengan produksi 2,19 ton sedangkan kopi robusta di luar kawasan hutan mencapai 65,14 $\mathrm{Ha}$ dengan produksi 24,50 ton dan kopi Arabika mencapai 77,75 Ha dengan produksi 13,85 ton (BPS, 2017). Produksi kopi yang cukup tinggi tersebut akan menghasilkan limbah berupa kulit kopi yang cukup tinggi pula, namun keberadaan kulit kopi belum dimanfaatkan oleh petani atau peternak secara maksimal.

Kulit kopi dapat digunakan sebagai pakan ternak, kandungan nutrisi berupa protein kasar sebesar $8,49 \%$ relatif sebanding dengan kandungan zat nutrisi rumput (Ismayadi, 2000). Kulit kopi yang diberikan 
secara langsung mudah rusak dan tidak disukai oleh ternak. Selain itu tingginya kandungan serat kasar dan adanya kandungan tanin, kafein dan lignin pada kulit kopi non fermentasi dapat mengganggu pencernaan ternak jika diberikan dalam jumlah banyak. Salah satu cara untuk meminimalkan faktor pembatas tersebut yaitu mengolah kulit kopi dengan cara fermentasi (Djajanegara dan Sitorus, 1983).

Fermentasi merupakan salah satu teknologi untuk meningkatkan kualitas pakan dan disukai ternak karena adanya aroma wangi dari hasil fermentasi (Sapienza dan Bolsen, 1993). Peningkatan kualitas pakan dapat dilakukan dengan cara fermentasi menggunakan jamur Trichoderma sp. (Daning dan Karunia, 2018). Uji organoleptik terhadap kualitas fisik fermentasi kulit kopi perlu dilakukan karena merupakan langkah awal dalam penentuan kualitas hasil fermentasi yang baik, berdasarkan warna, aroma, dan tekstur. Jika kualitas fisik sudah baik maka penelitian fermentasi kulit kopi dapat dilanjutkan dengan uji proksimat untuk mengetahui kualitas nutrisi dari hasil fermentasi kulit kopi.

Fermentasi kulit kopi dengan menggunakan jamur Trichoderma sp. dapat digunakan sebagai pengganti konsentrat karena kandungan protein kasar, lemak kasar dan serat kasar memenuhi syarat komposisi nutrien yang diberikan kepada ternak. Fermentasi kulit kopi dengan memanfaatkan Trichoderma sp. diharapkan mampu untuk meningkatkan kualitas fermentasi kulit kopi sehingga dapat menjadi pilihan untuk memenuhi kebutuhan pakan ternak dan dapat mempengaruhi protein kasar dari kulit kopi. Penelitian ini bertujuan untuk meningkatkan kualitas kulit kopi dengan cara fermentasi.

\section{MATERI DAN METODE}

Penelitian fermentasi kulit kopi dengan Trichoderma sp. ini telah dilaksanakan di
Laboratorium Pakan dan Nutrisi Ternak Politeknik Pembangunan Pertanian Malang.

\section{Materi Penelitian}

Fermentasi kulit kopi dengan 3 jenis bahan diantaranya air, tetes tebu, dan Trichoderma sp. Kulit kopi yang digunakan merupakan limbah dari tanaman kopi yang diperoleh dari Desa Andungsari, Kecamatan Pakem, Kabupaten Bondowoso.

\section{Metode Penelitian}

Sebanyak $9 \mathrm{ml}$ tetes tebu dicampurkan ke dalam $300 \mathrm{ml}$ air dan ditambahkan Trichoderma sp. sesuai perlakuan yang dihitung berdasarkan bahan kering kulit kopi, yaitu:

P0 $=$ Trichoderma sp. $(0 \%)$
P1 $=$ Trichoderma sp. $7,5 \mathrm{~g}(2,5 \%)$
P2 $=$ Trichoderma sp. $15,0 \mathrm{~g}(5,0 \%)$
P3 $=$ Trichoderma sp. $22,5 \mathrm{~g}(7,5 \%)$

Proses berikutnya bahan tersebut diaduk sampai homogen dan didiamkan selama 15 menit. Larutan yang telah homogen disiramkan pada $1 \mathrm{~kg}$ kulit kopi yang telah kering, bahan tersebut dicampurkan hingga merata, kemudian disimpan ke dalam plastik. Plastik yang telah terisi kulit kopi selanjutnya dilubangi sebanyak 8 tusukan di bagian pojok menggunakan jarum (semi-aerob). Sampel diberi label, kemudian disimpan pada tempat yang sejuk dan terhindar dari sinar matahari langsung selama 7 sampai 8 hari.

\section{Parameter}

Parameter yang diamati meliputi: nilai pH menggunakan kertas lakmus dan uji organoleptik dengan jumlah panelis sebanyak 12 peternak yang meliputi warna, aroma, dan tekstur.

\section{Nilai pH}

Nilai pH diuji menggunakan kertas lakmus. Fermentasi kulit kopi sebanyak $10 \mathrm{~g}$ ditambahkan dengan aquades $10 \mathrm{ml}$, kemudian dicampur dan diaduk hingga benarbenar melebur selama 15 menit hingga 
tercampur selanjutnya diukur dengan kertas lakmus.

\section{Uji Organoleptik}

Uji organoleptik dilakukan secara manual dimana panelis memberikan skor sesuai dengan petunjuk pelaksanaan penilaian.

Tabel 1. Skor Penilaian Uji Organoleptik

\begin{tabular}{|c|c|c|c|}
\hline Skor & Warna & Aroma & Tekstur \\
\hline 1 & $\begin{array}{l}\text { Coklat } \\
\text { kekuningan }\end{array}$ & Asam segar & Padat \\
\hline 2 & Coklat terang & Asam & $\begin{array}{l}\text { Agak } \\
\text { lembek }\end{array}$ \\
\hline 3 & $\begin{array}{l}\text { Coklat } \\
\text { kehitaman }\end{array}$ & Busuk & Lembek \\
\hline
\end{tabular}

\section{Rancangan Percobaan}

Penelitian ini menggunakan Rancangan Acak Lengkap (RAL) pola searah dengan 4 perlakuan dan 4 kali ulangan. Data penelitian dari hasil uji dianalisis dengan analisis variansi (ANOVA), jika terdapat pengaruh terhadap peubah yang berbeda maka dilanjutkan dengan uji lanjut Duncan Multiple Range Test (DMRT).

\section{HASIL DAN PEMBAHASAN}

\section{Kualitas Organoleptik}

Hasil pengamatan uji organoleptik dan nilai $\mathrm{pH}$ disajikan pada Tabel 2 .

Tabel 2. Hasil Uji Organoleptik dan Nilai pH dari Fermentasi Kulit Kopi

\begin{tabular}{ccccc}
\hline Perlakuan & Warna & Aroma & Tekstur & pH \\
\hline P0 & $2,0 \pm 0,15$ & $2,0 \pm 0,00$ & $1,2 \pm 0,05^{\mathrm{a}}$ & 6,0 \\
P1 & $1,8 \pm 0,06$ & $2,0 \pm 0,05$ & $1,9 \pm 0,02^{\mathrm{b}}$ & 5,5 \\
P2 & $1,9 \pm 0,03$ & $1,8 \pm 0,05$ & $1,8 \pm 0,08^{\mathrm{b}}$ & 5,5 \\
P3 & $1,9 \pm 0,04$ & $1,8 \pm 0,05$ & $2,0 \pm 0,08^{\mathrm{b}}$ & 5,5 \\
\hline
\end{tabular}

a,bSuperskrip yang berbeda pada kolom yang sama menunjukkan perbedaan yang nyata $(\mathrm{P}<0,05)$

\section{Warna}

Data hasil penelitian pada Tabel 2 . menunjukkan bahwa warna sampel kulit kopi yang difermentasi menggunakan Trichoderma sp. tidak berbeda nyata $(P>0,05)$ semuanya berwarna coklat terang. Hasil penelitian ini sesuai dengan hasil penelitian yang telah dilakukan oleh Munawaroh dan Lina (2017) yang menyatakan bahwa warna limbah daun angsana yang diinokulasi dengan Trichoderma sp. pada lama inkubasi 7 hari menunjukkan tidak ada perbedaan pada semua perlakuan yaitu berwarna coklat.

\section{Aroma}

Data hasil penelitian pada Tabel 2 . menunjukkan bahwa aroma sampel kulit kopi yang difermentasi menggunakan Trichoderma sp. tidak berbeda nyata $(P>0,05)$ semuanya berbau asam. Hal tersebut dikarenakan adanya aktivitas mikroba anaerob yang menyebabkan perubahan bau menjadi asam pada saat penyimpanan. Hasil penelitian (Islamiyati, 2013), jerami jagung yang diinokulasi oleh fungi Trichoderma sp. menghasilkan bau yang agak asam. Hal ini sesuai dengan hasil penelitian dari Aprintasari et al. (2012) yang menyatakan bahwa aroma kombinasi jerami yang difermentasi dengan isi rumen kerbau dapat menghasilkan aroma asam.

\section{Tekstur}

Hasil penelitian fermentasi kulit kopi dengan Trichoderma sp. pada level yang berbeda menunjukkan perbedaan yang nyata $(\mathrm{P}<0,05)$ terhadap tekstur. Semakin tinggi level Trichoderma sp. yang ditambahkan akan menghasilkan tekstur yang semakin lembek. Hal ini sesuai dengan penelitian yang dilakukan oleh Aprintasari et al. (2012) yang menyatakan bahwa tekstur dari daun angsana yang difermentasi dengan Trichoderma sp. menunjukkan hasil tekstur yang lembek. Hasil penelitian Islamiyati (2013) bahwa jerami jagung yang diinokulasi dengan Trichoderma sp. menghasilkan tekstur yang agak rapuh. Fermentasi pakan menggunakan Trichoderma 
sp. dapat memecah fraksi selulosa yang ada dalam kulit kopi dan daun angsana karena proses fermentasi tersebut mensekresikan enzim selulase (Kodri et al., 2013).

\section{Nilai pH}

Hasil uji pH yang dilakukan dapat diketahui pada Tabel 2. Nilai $\mathrm{pH}$ fermentasi kulit kopi dari 3 sampel diperoleh $\mathrm{pH}$ sebesar 5,5 dan 6. Hal ini berarti mikroba Trichoderma sp. dapat tumbuh pada kulit kopi tersebut dan memecah sumber serat dan kulit kopi menjadi asam laktat (Daning dan Karunia, 2018) dan sesuai dengan hasil penelitian Rihadini et al. (2017) menunjukkan bahwa penambahan starter Trichoderma harzianum sebesar 2\% menunjukkan nilai pH sebesar 5,18.

Hasil uji pH fermentasi kulit kopi dengan Trichoderma sp. dari 16 sampel yang diuji diketahui perlakuan $\mathrm{P0}$ memiliki ratarata $\mathrm{pH}$ sebesar 6 , sedangkan $\mathrm{pH}$ perlakuan (P1, P2, dan P3) memiliki pH sebesar 5,5. Hal ini berarti mikroba Trichoderma sp. dapat tumbuh pada kulit kopi tersebut dan diperoleh pemecahan sumber serat dari kulit kopi menjadi asam laktat (indikator pH asam). Pertumbuhan Trichoderma harzianum lebih cocok pada kondisi asam dan kapang pada umumnya akan menunjukkan pertumbuhan terbaik pada kondisi asam atau $\mathrm{pH}$ rendah (Uruilal et al., 2012).

\section{KESIMPULAN DAN SARAN}

\section{Kesimpulan}

Fermentasi limbah kulit kopi menggunakan Trichoderma sp. menghasilkan kualitas dengan warna rata-rata coklat terang, aroma asam, dan tekstur yang semakin lembek dengan peningkatan persentase pemberian Trichoderma sp. Nilai $\mathrm{pH}$ fermentasi limbah kulit kopi menggunakan Trichoderma sp. adalah sekitar 6.

\section{Saran}

Saran yang dapat diberikan dalam penelitian ini yaitu perlu adanya penelitian lebih lanjut untuk mengetahui pengaruh fermentasi kulit kopi dengan Trichoderma sp. terhadap pakan sapi potong.

\section{DAFTAR PUSTAKA}

Aprintasari, R., C.I. Sutrisno, dan B.I.M. Tampoeboelon. 2012. Uji total fungi dan organoleptik pada jerami padi dan jerami jagung yang difermentasi dengan isi rumen kerbau. Jurnal Animal Agriculture. 1(2):311-321.

BPS. 2017. Kecamatan Pakem dalam Angka 2017. Badan Pusat Statistik. Yogyakarta.

Daning, D.R.A. dan A.D Karunia. 2018 Teknologi fermentasi menggunakan kapang Trichoderma sp. untuk meningkatkan kualitas nutrisi kulit kopi sebagai pakan ternak ruminansia. Agriekstensia. 17(1):70-76.

Djajanegara, A. dan P. Sitorus. 1983. Problematika pemanfaatan limbah pertanian untuk makanan ternak. Jurnal Litbang. 11(2).

Islamiyati, R. 2013. Penggunaan Jerami Jagung yang Diinokulasi Fungi Trichoderma sp. dan Diperikaya Daun Gamal Sebagai Pakan Ternak Ruminansia. PPS Universitas Hasanuddin Makassar.

Ismayadi, C. 2000. Perkembangan teknologi pengolahan kopi arabika di Indonesia. Warta Pusat Penelitian Kopi dan Kakao Indonesia. 16:239-251.

Kodri, K., B.D. Agro, dan R Yulianingsih. 2013. Pemanfaatan enzim selulase dari Trichoderma reseei dan Aspergillus niger sebagai katalisator hidrolisis enzimatik jerami padi dengan pretreatment microwave. Jurnal Bioproses Komoditas Tropis. 1(1):36-43.

Munawaroh, F.Y. dan A. Lina. 2017. Aplikasi Trichoderma $s p$. terhadap kualitas fermentasi limbah daun angsana (Pterocarpus indicus Wild). Seminar Nasional UNIKAMA. Malang.

Rihadini, R.A., S. Mukodiningsih, dan S. Sumarsih. 2017. Kualitas fisik organoleptik limbah tauge kacang hijau yang difermentasi menggunakan Tricodherma harzianum dengan level yang berbeda. Jurnal Ilmiah Peternakan Terpadu. 5(2):28-32.

Sapienza, D.A. dan K.K. Bolsen. 1993. 
Teknologi Silase. Penerjemah: Martoyondo Rini BS. England: Pioneer Hi-Bred International Inc.

Uruilal, C., A.M. Kalay, E. Kaya, dan A. Siregar. (2012). Pemanfaatan kompos sagu, sekam dan dedak sebagai media perbanyakan agen hayati Trichoderma harzianum. Agrologia. 1(1):21-30. 